\title{
What determines testosterone levels?
}

\author{
Jun Kawakami, MD, FRCSC; Premal Patel \\ Division of Urology, University of Calgary, Calgary, AB
}

See related article on page 183.

Cite as: Can Urol Assoc J 2012;6(3):187. http://dx.doi.org/10.5489/cuaj.12115

$\mathrm{T}$ his study is interesting as a negative study. It shows that the type of luteinizing hormone releasing-hormone (LHRH) agonists and primary therapy is not significant when it comes to testosterone levels. ${ }^{1}$ This commentary focuses on the actual testosterone levels, which are clinically relevant as many patients were experiencing breakthrough levels on LHRH agonists.

Chemically castrate status in terms of testosterone has been argued to be $20 \mathrm{ng} / \mathrm{dL}$ or $50 \mathrm{ng} / \mathrm{dL}$, which converts to $0.69 \mathrm{nmol} / \mathrm{L}$ or $1.7 \mathrm{nmol} / \mathrm{L} .{ }^{2}$ Current consensus is $20 \mathrm{ng} /$ $\mathrm{dL}$, which bilateral surgical castration typically achieves. ${ }^{3}$ The median values reported in this study for $\mathrm{LHRH}$ alone, radiation and surgery were 40,37 and $36 \mathrm{ng} / \mathrm{dL}$, or 1.4 , 1.3 and $1.25 \mathrm{nmol} / \mathrm{L}$, respectively. The interquartile ranges also suggest that most patients $(75 \%)$ did not have castrate levels of testosterone.

Admittedly, this study does mention testosterone was only obtained once and circumstances surrounding it were uncertain. Anti-androgen status is also not mentioned. Bicalutamide and other anti-androgens are known to elevate testosterone levels as monotherapy and may have a confounding effect on the testosterone levels reported.

Most likely testosterone was measured when prostatespecific antigen (PSA) was rising on LHRH agonist and one can surmise that the ordering physician was looking for and found "testosterone escape" (a single value above $50 \mathrm{ng} /$ $\mathrm{dL}$ or $1.7 \mathrm{nmol} / \mathrm{L}$ ) in many of the patients in this study. ${ }^{4}$ Although as stated previously, perhaps $20 \mathrm{ng} / \mathrm{dL}$ should be the current definition.

The importance of testosterone escape is backed by several studies. It is known anti-androgens do not help orchiectomy patients in overall survival, but do for patients on LHRH agonists. ${ }^{5}$ Breakthrough testosterone levels on medication that did not occur for surgically castrate patients would be a likely explanation. Progression-free survival in non-metastatic patients in another study was longer, the lower the testosterone level. ${ }^{6}$

In this clinical scenario of testosterone escape, standard treatment was switching LHRH agonists, adding an antiandrogen and bilateral orchiectomy. Now, a new option with LHRH antagonists arises. It has been reported to have modest results with respect to decreasing PSA, but can possibly alleviate voiding symptoms more than LHRH agonist therapy. ${ }^{7}$

Regardless, the actual testosterone level is important for patients on LHRH agonists with rising PSA. Venkateswaran and colleagues make the case that it should be checked no matter what the primary therapy. ${ }^{1}$

Competing interests: None declared.

This paper has been peer-reviewed.

\section{References}

1. Venkateswaran $S$, Margel D, Yap $S$, et al. Comparison of serum testosterone levels in prostate cancer patients receiving LHRH agonist therapy with or without the removal of the prostate. Can Urol Assoc J 2012;6:183-6. htrp://dx.doi.org/10.5489/cuaj.11278

2. SI Units for Clinical Data. http://www.unc.edu/ rowlett/units/scales/clinical_data.html (Accessed May 9, 2012).

3. de Jong IJ, Eaton A, Bladou F. LHRH agonists in prostate cancer: frequency of treatment, serum testosterone measurement and castrate level: consensus opinion from a roundtable discussion. Curr Med Res Opin 2007;23:1077-80. http://dx.doi.org/10.1185/030079907X187973

4. Sharifi R, Browneller R; Leuprolide Study Group. Serum testosterone suppression and potential for agonistic stimulation during chronic treatment with monthly and 3-month depot formulations of leuprolide acetate for advanced prostate cancer. J Urol 2002;168:1001-4. http://dx.doi.org/10.1016/50022$5347(05) 64560-0$

5. Maximum androgen blockade in advanced prostate cancer: an overview of the randomised trials. Prostate Cancer Trialists' Collaborative Group. Lancet 2000;355:1491-8. http://dx.doi.org/10.1016/50140$6736(00) 02163-2$

6. Morote J, Orsola A, Planas J, et al. Redefining clinically significant castration levels in patients with prostate cancer receiving continuous androgen deprivation therapy. J Urol 2007;178:1290-5. hitp:// dx.doi.org/10.1016/i.juro.2007.05.129

7. Axcrona K, Aaltomaa S, da Silva CM, et al. Androgen deprivation therapy for volume reduction, lower urinary tract symptom relief and quality of life improvement in patients with prostate cancer: degarelix vs goserelin plus bicalutamide. BJU Int 2012; Apr 13. http://dx.doi.org/10.1111/i.1464-410X.2012.11107 [Epub ahead of print]

Correspondence: Dr. Jun Kawakami, Southern Alberta Institute of Urology, 7007 14th Street SW, Calgary, AB T2V 1P9; kawakamijun@me.com 